\title{
Capital Budgeting Practice of Thai Firms
}

\author{
${ }^{1}$ Kereboon Champathed*, ${ }^{2}$ Chuvej Chansa-ngavej \\ ${ }^{1}$ Shinawatra International University, Thailand \\ ${ }^{2}$ Suvarnabhumi Institute of Technology, Thailand \\ *katumboy@hotmail.com
}

\begin{abstract}
This paper examines the capital budgeting practice of Thai firms and the relationships between capital budgeting techniques and the firm size, length of operation and type of firms. The results indicated that most Thai firms used capital budgeting techniques for the analysis of investment projects (74.1\%) and more than half $(51.7 \%)$ of total corporate capital investment expenditures were screened by capital budgeting techniques. Discounted-cash-flow techniques were used by the majority of the firms with Internal Rate of Return (IRR) the most used evaluate techniques. Moreover, risk is quantified on individual project basis in assessing risk in investment decisions. Shortening the desired payback period was used most among the risk analysis techniques and the most likely scenario received most attention in the financial justification in relation to risk.
\end{abstract}

Keywords: Capital budgeting techniques, discounted-cash-flow, NPV, IRR, PB, Thai firms

\section{Introduction}

Most firms have sophisticated evaluation techniques for investment projects involving capital budgeting for uses as important tools for financial managers. Capital budgeting decision process remains one of the key contemporary management problems. The results help mold the firm's future opportunities. Capital budgeting is very important for the firm because it involves large amount of capital investment budget and capital is a very limited resource for most firms. Although banks may extend loans to a company, they mostly come with strings attached so that the managers would need to consider the impact before investment. The financial managers have to weigh the pros and cons carefully before any capital investment decision making. Capital budgeting contains procedures to evaluate, compare and select projects. Capital budgeting aims to choose investment projects with satisfactory cash flows and rates of return. Capital budgeting techniques helped financial decision-making in the past (Ryan \& Ryan 2002; Schall et al., 1978). Researches had examined the circumstances in which the use of Discounted Cash Flow (DCF) methods or may not be beneficial.

Capital budgeting is important for the companies that want to make profit for the investors and share profits as dividends to stakeholders, including shareholders, management and employees in the company. According to Brigham \& Houston (2009) two key factors combine to make capital budgeting important, they are large amount of asset and long period of investment to return. The capital budgeting still defines the strategic of company to create new products, services or marketing in research. Financial managers need to consider the investments. According to Gitman \& Forrester jr, (1977) capital budgeting techniques are the main tools in the evaluation of the project. Academics have preached the use of more sophisticated capital budgeting analysis approaches in large companies with high cost and large number of employees. They further suggest the risk assessment of projects. According to Brealey et al. (2014) smart financial managers must consider risk together with capital budgeting.

There have been many firms using capital budgeting techniques in past decades. It has been wellestablished that capital budgeting techniques were used widely to select projects were many firms used capital budgeting, particularly in the United States. As most past surveys were conducted overseas, it is interesting to know whether the firms in Thailand follow a similar pattern in the use of capital budgeting techniques. This article surveys the level of sophistication used in capital budgeting by the nation's leading firms. The purpose of this paper is to find out how Thai firms use these methods in practice at present. This survey thus studies capital budgeting techniques of Thai firms and the factors relating to their use of evaluation techniques for investment projects in Thailand. The Hypotheses consist of:

- Null Hypothesis (1) Type of firms affects the use of capital budgeting techniques.

- Null Hypothesis (2) Length of operations affects the use capital budgeting techniques more. 
- Null Hypothesis (3) Size of firms affects the use of capital budgeting techniques.

\section{Literature Review}

Capital Budgeting: It is important to note that capital is a very limited resource. Commercial banks and other lending institutions have limited deposits from which they can lend money to individuals, corporations, and governments. The management of company would need to consider the impact that increasing loans would have on the overall cost of financing. The limited sources of capital management should carefully decide whether a particular project is economically acceptable. The managers must identify the projects that contribute most to profits and, consequently, to the value (or wealth) of the firm. This essence is the basis of capital budgeting. Capital budgeting is the tool going on processing to identify and select projects in a long term. It is managerial tool that plan for rising large and long-term. Financial manager discusses investments with satisfactory cash flows and rates of return. Techniques in capital budgeting such as Internal Rate of Return (IRR), net present value (NPV), and payback period (PB) are used in creating capital budgets. Capital budgeting procedure to evaluate, compare, and select projects is needed. Three major techniques for making decisions involve (1) accounting return on investment (2) Payback period, and (3) discounted cash flows. Each technique addresses the problem by focusing on a different specific question. Discounted cash flow techniques ask how the present value of future benefits from the investment fare compared to the investment outlay.

Payback Period is the measure of capital investment desirability which was developed before discounted cash flow techniques were widely understood. This measure is still used as primary decision criteria for some firms. The payback period is the number of years until the cumulative cash benefit equals the money invested. Payback was the principle capital budgeting criterion for a number of years. The reason for its popularity is the ease to explain the rule to employees with no background in finance. The payback period is also used as a risk measure. The longer time it takes to cover the original investment, the more risk and the chance there is something to go wrong. Payback period is used primarily as supplementary information. Managers relied on payback in earlier years.

Net Present Value is the method which improves the effectiveness of project evaluations. This method which relies on discounted cash flow (DCF) techniques that proceed as follows: 1) Find the present value of each cash flow, including both inflows and outflows, discounted at the project's cost of capital 2) Sum these discounted cash flows: this sum is defined as the project's NPV 3) If the NPV is positive, the project should be accepted, while if the NPV is negative, it should be rejected. If the projects with positive NPVs are mutually exclusive, the one with the higher NPV should be chosen.

Internal Rate of Return is a yield, on average, per year. The IRR is defined as the discounted cash rate that equates the present value of a project's expected cash inflows to the present value of the project's costs: PV (inflows) =PV (investment costs) or the rate that forces the NPV to equal zero. The decision rule for the Internal Rate of Return is to invest in a project if it provides a return greater than the cost of capital. The cost of capital, in the context of the IRR, is a hurdle rate, the minimum acceptable rate of return

Profitability Index is the ratio of the present value of change in operating cash inflows to the present value of investment cash outflows. PI is the ratio of the tow present values. The PI is often referred to as the benefit-cost ratio, since it is the ratio of the benefit from an investment to its cost. PI tells how much value we get for investment. The rule is PI is greater than one, we accept it. Capital investment projects are classified by project life within short- term or long- term. The long-term projects, in case of long term, the time value of money plays an important role. Long-term asset are based on projections of cash flows far into the future and consider the time value of money. Investment provides benefits over a limited period of time, referred to as its economic life asset by physical deterioration, obsolescence or the degree of competition in the market for a product.

Risk: In practice it is difficult to estimate the value of future cash flow with a single figure. In high uncertainty situations, the firm may take consideration multiple cash flow estimates (Chansa-ngavej, 2009). Since the future is normally uncertain, the use of multiple cash flow estimates is the norm. For the evaluation to be meaningful, the manager must evaluate the risk that means the cash flows will differ from what is expected. The risk is degree of uncertainty; the uncertainty arises from different sources, depending on the type of investment as well as circumstance and industry in which it is operating. Uncertainty may result from economic conditions, market conditions, taxes, interest rate and international conditions. In evaluating capital projects, the decision makers are concerned with measuring risk. Risk means exposure to chance of loss of money or get back less than expected (Seitz \& 
Ellison, 2005). The investor likes the return and dislikes risk. Before investing if they expect higher returns, they need to take higher risks. The manager uses measured risk and assesses the tradeoff between risk and return. All financial assets are expected to produce cash flows, and the riskiness of an asset is judged in terms of the riskiness of its cash flows. The riskiness of an asset can be considered in two ways: (1) on standalone basis (2) where the cash flows from a number of assets are combined, then the consolidated cash flows are analyzed. The investment may be much less risky if it is held as part of a larger portfolio. In portfolio context, an asset's risk can be divided into two components: (a) diversifiable risk and (b) market risk.

\section{Methodology}

This research studies capital budgeting techniques used in Thai firms. Thailand still has not much information on capital budgeting techniques that are widely used. The accurate information is important for the research methodology, as defined by the split into groups, for example, and sampling is carried out. Population and Sample Sizes are 240 firms as appeared in Stock Exchange of Thailand (SET)-listed 605 companies by sending questionnaire, also taking into consideration the expert respondent will be required to take part in the decision or participate in the evaluation of the project. The respondents are mostly financial managers, vice presidents of finance, directors of facilities management, or chiefs of finance. A total of $56 \%$ of the subjects responded to the questionnaire. The questionnaire consists of two parts. The first part involves selecting answers. In the second part the respondent profile (using multiple choices) is provided. The questionnaire asks the personal data to be answered via questions regarding age, etc. The statistical computer software was employed to analyze data using appropriate statistical methods.

\section{Results}

In this part, the empirical results regarding the capital budgeting practice in Thailand were elaborated and compared to the past studies by several well-known authors described in Section 1.

The firm used capital budgeting techniques: The questionnaire collects information on how capital budgeting techniques are used in practice to evaluate project consist of type of investment project, percentage of total corporate capital investment expenditures, the methods that the company uses in evaluating investment projects, assessing risk in investment decision, using risk analysis techniques and cash-flow scenario that received most attention in the financial justification.

Table 1: Type of investment projects which analyze with capital budgeting techniques

\begin{tabular}{lll}
\hline Type of investment projects & Frequency & Percentage \\
\hline All & 100 & 74.1 \\
For certain types of projects & 20 & 14.8 \\
None of the investment projects & 15 & 11.1 \\
Total & 135 & 100.0 \\
\hline
\end{tabular}

Most firms in Thailand used capital budgeting techniques to analyze all projects (74.1\%), followed by for certain types of project (14.8\%), and none of the investment projects is the least at $11.1 \%$.

Table 2: Percentage of total corporate capital investment expenditures that are analyzed with capital budgeting techniques

\begin{tabular}{lll}
\hline Percentages of total corporate & Frequency & Percentage \\
\hline No Entry & 19 & 14.1 \\
1 & 1 & .7 \\
2 & 1 & .7 \\
5 & 2 & 1.5 \\
10 & 10 & 7.4 \\
15 & 1 & .7 \\
20 & 7 & 5.2 \\
25 & 3 & 2.2 \\
30 & 13 & 9.6 \\
40 & 9 & 6.7 \\
45 & 1 & .7 \\
50 & 13 & 9.6
\end{tabular}




\begin{tabular}{lll}
\hline Percentages of total corporate & Frequency & Percentage \\
\hline & & \\
60 & 12 & 8.9 \\
65 & 1 & .7 \\
70 & 15 & 11.1 \\
75 & 2 & 1.5 \\
80 & 14 & 10.4 \\
90 & 1 & .7 \\
100 & 10 & 7.4 \\
Total & 135 & 100.0 \\
\hline
\end{tabular}

The mean value of percentage of total corporate capital investment expenditures that are analyzed with capital budgeting techniques is found to be $51.7 \%$.

Table 3: The methods company use to evaluate investment projects in capital budgeting process

\begin{tabular}{lll}
\hline The method & Frequency & Percentage \\
\hline NPV & 16 & 11.9 \\
IRR & 23 & 17.0 \\
PB & 19 & 14.1 \\
Strategy & 13 & 9.6 \\
NPV, IRR & 4 & 3.0 \\
NPV, PB & 4 & 3.0 \\
NPV, Other & 1 & .7 \\
NPV, Strategy & 5 & 3.7 \\
IRR, PI & 9 & 6.7 \\
IRR, Other & 1 & .7 \\
IRR Strategy & 1 & .7 \\
PI, Other & 5 & 3.7 \\
PI, Strategy & 8 & 5.9 \\
Other, Strategy & 1 & .7 \\
NPV, IRR, PI & 8 & 5.9 \\
NPV, IRR, Strategy & 1 & .7 \\
NPV, PI, Strategy & 1 & .7 \\
IRR, PI, other & 1 & .7 \\
IRR, PI, Strategy & 5 & 3.7 \\
NPV, IRR, PI, other & 1 & .7 \\
NPV, IRR, PI, Strategy & 6 & 4.4 \\
NPV, IRR, PI, Other, Strategy & 2 & 1.5 \\
Total & 135 & 100.0 \\
\hline
\end{tabular}

Most firms in Thailand use Internal Rate of Return methods (IRR) to evaluate investment project in capital budgeting process. The second is Payback Period (PB). The least is other cash flow based techniques.

Table 4: Assessing risk in investment decision

\begin{tabular}{lll}
\hline Type of assessing risk & Frequency & Percentage \\
\hline Risk is quantified on individual project basis & 118 & 87.4 \\
Risk is assessed subjectively & 7 & 5.2 \\
Risk is not assessed at all & 10 & 7.4 \\
Total & 135 & 100.0 \\
\hline
\end{tabular}

Most firms in Thailand use risk quantified on individual project basis in assessing risk investment decision (87.4\%). The rest is $5.2 \%$ risk is assessed subjectively, and $7.4 \%$ risk is not assessed at all. 
Table 5: Using risk analysis techniques

\begin{tabular}{lll}
\hline Risk techniques & Frequency & Percentage \\
\hline Increasing the minimum acceptable rate of return & 29 & 24.8 \\
Shortening the desired payback period & 37 & 25.7 \\
Sensitivity analysis & 28 & 22.0 \\
Considering probability distribution and risk simulation & 30 & 22.9 \\
Comparative analysis of different cast flow scenarios & 21 & 13.8 \\
Measuring covariance of projects & 25 & 15.6 \\
Others & 1 & 0.9 \\
Total & 135 & 100.0 \\
\hline
\end{tabular}

Most firms in Thailand use shortening the desired payback period in risk analysis techniques (25.8\%), followed by sensitivity analysis at $24.8 \%$.

Table 6: Cash-flow scenario receives most attention in the financial justification

\begin{tabular}{lll}
\hline Cash flow scenario & Frequency & Percentage \\
\hline Worst case scenario & 29 & 21.5 \\
Pessimistic scenario & 19 & 14.1 \\
Most likely scenario & 79 & 58.5 \\
Optimistic scenario & 7 & 5.2 \\
Others & 1 & 0.7 \\
Total & 135 & 100.0 \\
\hline
\end{tabular}

Most firms in Thailand use most likely scenario in assessing risk investment decision (58.5\%), followed by worst case scenario at $21.5 \%$.

Table 7: Amount of employee in firm

\begin{tabular}{lll}
\hline Size of firms & Frequency & Percentage \\
\hline Fewer than 50 full time employees & 35 & 25.9 \\
Between 50-100 full time employees & 38 & 28.1 \\
More than 151 full time employees & 63 & 45.9 \\
Total & 135 & 100.0 \\
\hline
\end{tabular}

Most firms in Thailand which respond to the questionnaire have more than 151 full time employees (45.29\%), followed by $25.9 \%$ for fewer than 50 full time employees.

Table 8: Size of firm affecting project evaluation

\begin{tabular}{lcccll}
\hline \multicolumn{1}{c}{ Size of firm } & SS & df & Mean Square & F & Sig. \\
\hline Between Groups 2.663 & 2 & 1.384 & 1.474 & .233 \\
Within Group & 119.219132 & .903 & & & \\
Total & 121.881134 & & & \\
\hline
\end{tabular}

The size of Thai firms is not significant so that it is no effect to using capital budgeting techniques.

Table 9: Type of productive firm

\begin{tabular}{lll}
\hline Type of firms & Frequency & Percentage \\
\hline Service firms & 30 & 22.2 \\
Merchandising firm & 9 & 6.7 \\
Manufacturing firm & 87 & 64.4 \\
Other & 9 & 6.7 \\
Total & 135 & 100.0 \\
\hline
\end{tabular}

The firms in Thailand which respond to the questionnaire mostly is manufacturing firm, $64.4 \%$, followed by service firm, $2.22 \%$. The rest is $6.7 \%$ that is merchandising and others. 
Table 10: Type of productive firm

\begin{tabular}{lccll}
\hline \multicolumn{1}{c}{ Type of firm SS } & df & Mean Square & F & Sig. \\
\hline Between Groups .790 & 3 & .263 & .285 & .836 \\
Within Group & 121.091131 & .924 & & \\
Total & 121.881134 & & & \\
\hline
\end{tabular}

The type of firms in Thailand is not significant so that it has no effect to using capital budgeting techniques.

Table 11: Periods the company has been in operation

\begin{tabular}{lll}
\hline Length of operation & Frequency & Percentage \\
\hline 1-10 years & 41 & 30.4 \\
11-20 years & 46 & 34.1 \\
21-30 years & 23 & 17.0 \\
31-40 years & 19 & 14.1 \\
$41-50$ years & 4 & 3.0 \\
51 up years & 2 & 1.5 \\
Total & 135 & 100.0 \\
\hline
\end{tabular}

The firms in Thailand which respond to the questionnaire mostly have length of operation 11-20 years (34.1\%). The second is $1-10$ years $(30.4 \%)$.

Table 12: Length in operation of firms affecting project evaluation

\begin{tabular}{lllcll}
\hline \multicolumn{1}{c}{ Length in operation } & SS & df & mean Square & F & Sig. \\
\hline Between Groups & 2.589 & 5 & .518 & .560 & .731 \\
Within Group & 119.293129 & & .925 & & \\
Total & 121.881134 & & & & \\
\hline
\end{tabular}

The lengths in operation of firms in Thailand are not significant so that it has no effect on using capital budgeting techniques.

Discussion of Results: The results of the capital budgeting techniques used by Thai firms were elaborated and compared to past studies which showed that most Thai firms use capital budgeting techniques for the analysis investment projects at $74.1 \%$ (Table 1 ). Thirty years ago, there were several surveys about firms in U.S. that capital budgeting techniques were used widely to evaluate projects (Gitman \& Forrester jr, 1977; Pike, 1996). As firms in neighboring Asian countries also used capital budgeting techniques (Chen, 2008), so that the capital budgeting was useful for decision making. According to Peterson and Fabozzi, (2002), financial managers have used capital investment techniques to assess the investment projects. At present, they use technology to help in the work to improve performance by information technology so that makes the appraisal techniques more widely used. According to Ryan and Ryan, (2002), it was found that while the survey results reflect the increased financial sophistication and availability of inexpensive computer technology, it was shown that the discounted cash flow techniques are the most frequently cited capital budgeting tool.

Despite the widespread use of capital budgeting techniques, firms were not using them for all projects. The capital budgeting techniques were found to be applied to just $51.7 \%$ of total corporate capital investment expenditures (Table 2). Because there are other methods that are appropriate for certain circumstances, it is interesting to investigate further to establish the circumstances that capital budgeting techniques are not appropriate (Chen, 2008). For the rest of total corporate capital investment expenditures, they use capital budgeting techniques to evaluate just $25.8 \%$. In Table 3, there are firms that still use other methods to evaluate projects such as claiming strategic advantage as the reason for project investment. That is why total corporate capital investment expenditures that use capital budgeting techniques is a mere $51.7 \%$. The Discounted cash flow method most used is Internal Rate of Return (IRR) (Table 4). Other scholars of the technique most commonly used is the Internal Rate of Return (IRR) and to evaluate investment project. This is consistent with past studies (Gitman \& Forrester jr, 1977). The most popular sophisticated technique is Internal Rate of Return (IRR) the use of which increased steadily. As the project IRR provides a return greater than the cost of capital. It measures yield, and therefore easy to understand (Peterson \& Fabozzi, 2002). This confirms Ryan \& Ryan, (2002) which 
found that financial managers prefer methods such as Internal Rate of Return. Moreover, there are firms use multi techniques to evaluate projects.

The Thai firms mostly account for risk by quantifying on individual project basis (Table 5), because financial managers must measure risk and address the relationship between risk and return. Decision maker also are concerned with measuring risk (Peterson \& Fabozzi, 2002). As shown in Table 6 for using risk analysis techniques, most Thai firms use shortening the desired payback period, or the required rate of return, or raising the discount rate in computing present value (Schall et al., 1978). The project's future cash flows are uncertain so that extra compensation for risk is required (Peterson \& Fabozzi, 2002). Most likely scenario received most attention in the financial justification. According to Gitman \& Forrester jr. (1977) firms often gave explicit consideration to risk and uncertainty. Formal risk appraisal methods are often incorporated in capital budgeting (Pike, 1996). Most firms in Thailand which respond to the questionnaire have more than 151 full time employees (45.3\%) (Table 7). The type of firms (Table 8) mostly is manufacturing firm, at $64.4 \%$, followed by service firms, $2.22 \%$. The rest $(6.7 \%)$ are merchandising firms and others. The length of operation of most firms is 11-20 years (34.1\%) (Table 9), following by 1-10 years (30.4\%). All of the factors, size of firms, type of firms and length of operation are found by one way ANOVA tests that there is no effect. This is perhaps because most firms in Thailand use capital budgeting techniques to analyze investment projects (74.1\%) so that the factors relating to firm characteristics are not significant. According to Sangster (1993) it was found that since hardware and software costs for information technology are down, using DCF techniques is a relatively straightforward task for even the smallest firms, a fact contributing to erosion of the relationship between size and the selection of quantitative appraisal techniques.

\section{Conclusion}

In conclusion, the empirical result was found on Capital budgeting techniques used by Thai firms. According to Schall et al. (1978) survey in U.S. firms more than three decades ago that the firms tend to use sophisticated capital budgeting techniques widely. This paper shows how capital budgeting techniques are used in Thai firms. It compares and contrasts the use of methods between U.S. firms 30 years ago and Thai firms at present. It is shown that most Thai firms use capital budgeting techniques analysis of investment projects (74.1\%). The level of sophistication appears quite high. As Schall et al. (1978) surveyed the U.S. firms in 1978. This paper takes the result to compare with Thai firms at present. Fig. 1 show the U.S. firms and their use of capital budgeting techniques and the total corporate capital investment expenditures use capital budgeting techniques applied 30 years ago compared to the results for Thai firms in 2014.

Table 13: Comparison on how capital budgeting techniques are used between U.S. firms 30 years ago and Thai firms at present

\begin{tabular}{llll}
\hline Tend to used capital budgeting techniques & $\begin{array}{l}\text { U.S. } \\
\mathbf{( \% )}\end{array}$ & $\begin{array}{l}\text { firms } \\
\text { Thai }\end{array}$ & $\begin{array}{l}\text { firms } \\
(\%)\end{array}$ \\
\hline - Using CPT analyze all type of investment projects & 77 & 74.1 & \\
- Percentage of total corporate capital investment expenditures are capital & 83.2 & & 51.7 \\
budgeting techniques applied. & & & \\
\hline
\end{tabular}

Figure 1: Comparison of use of capital budgeting techniques between U.S. firms at last 30 years and Thai firms at present

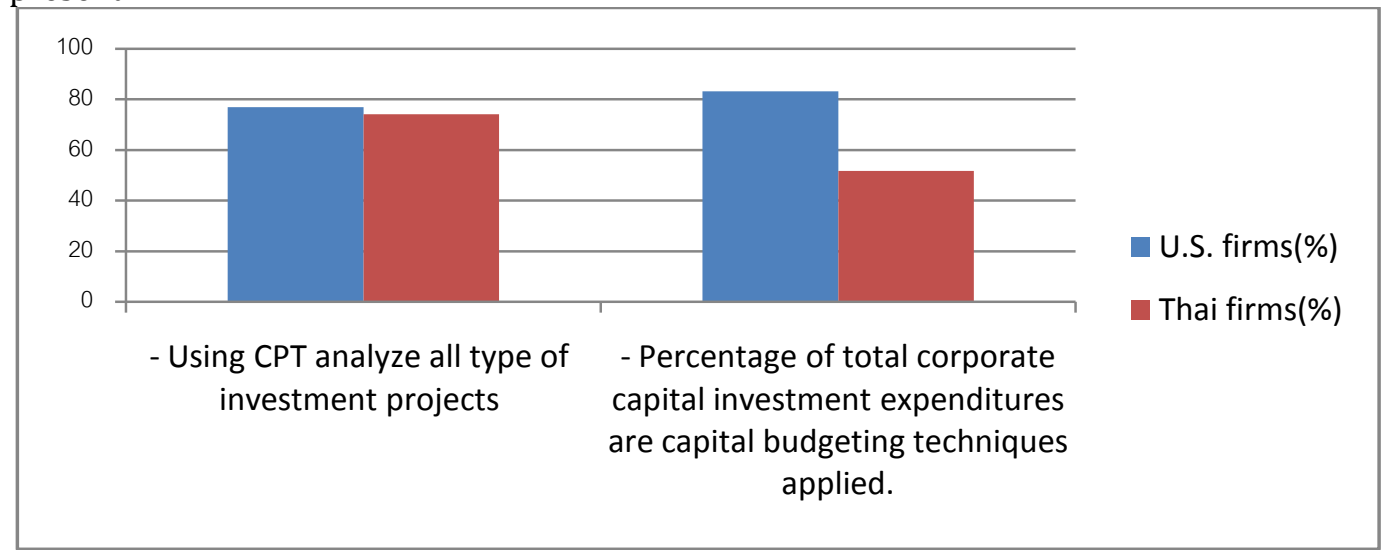


Recommendations: The recommendations for the future research of this papers, the researcher should investigate others variables in this papers such a amount of capital, education of decision maker and contingency approach that is criterion to determine capital investment projects (Champathed \& Chansangavej, 2012). Most financial managers use capital budgeting techniques. However it is not for all projects since the methods are not always appropriate (Myers 1984). There are many Thai firms that use both capital budgeting techniques and non financial. This confirms Ong and Teh (2009) which found that firms are more likely to rely on both financial and non-financial performance. There are many firms that use a combination of techniques (Pike, 1996). It is recommended that sophisticated tools be used to support decision making to select project investment. According to Ingman \& Takala (2010) it is of research interest to identify and examine the critical measures of success for future investment projects. This represents a fertile area for future research.

\section{References}

Brealey, R. A., Myers, S. C. \& Allen, F. (2014). Principles of Corporate Finance (11 th ed.). McGraw-Hill, New York.

Brigham, E. F. \& Houston, J. F. (2009). Fundamentals of Financial Management. (6 $6^{\text {th }}$ ed.) Thomson SouthWestern, Mason, Ohio

Champathed, K. \& Chansa-ngavej, C. (2012). A contingency model of capital budgeting decisions in the new economy. International Seminar on Science and Technology Innovations 2012. Jakarta.

Chansa-ngavej, C. (2009). Total Profitability Analysis. Sinthu Creation, Bangkok.

Chen, S. (2008). DCF techniques and nonfinancial measures in capital budgeting: a contingency approach analysis. Behavioral Research in Accounting, 20(1), 13-29.

Gitman, L. J. \& Forrester jr, J. R. (1977). Forecasting and evaluation practices and performance: a survey of capital budgeting . Financial Management, 6(3), 66-71.

Ingman, L. \& Takala, J. (2010). Measuring CS by critical factor index in pricing process. Proceedings of the 7th International Conferece on Innovation\& Management, pp. 665-671.

Klammer, T. (1972). Empirical evidence of the adoption of sophisticated capital budgeting techniques. The Journal of Business, 45(3), 387-397.

Mukherjee, T. K. (1993). The capital budgeting process of large U.S. firms; an analysis of capital budgeting manuals. Managerial Finance, 14(2), 28-35.

Myers, S. C. (1984). Finance theory and financial strategy. Interfaces, 14(1), 126-137.

Ong, T. S. \& Teh, B. H. (2009). The use of financial and non-financial performance measures in the malaysian manufacturing companies. ICFAI Journal of Accounting Research, 8(1), 23-30.

Peterson, P. P. \& Fabozzi, F. J. (2002). Capital budgeting: Theory and Practice. Willey, New York.

Pike, R. (1996). A longitudinal survey on capital budgeting practices. Journal of Business Finance \& Accounting, 23(1), 79-92.

Ryan, P. A. \& Ryan, G.P. (2002). Capital budgeting practices of the Fortune 100": how have things changed? Journal of Business \& Management, 8(4), 355-364.

Sangster, A. (1993). Capital investment appraisal techniques: a survey of current usage. Journal of Business Finance \& Accounting, 20(3), 307-332.

Schall, L. D., Sundem, G. L. \& Geijsbeek Jr., W. R. (1978). A survey and analysis of captial budgeting methods. Journal of Finance, 33(1), 281-287.

Seitz, N. \& Ellison, M. (2005). Capital Budgeting and Long-Term Financing Decisions. Southwestern, Mason, Ohio 